\title{
Using High School Football to Promote Life Skills and Student Engagement: Perspectives from Canadian Coaches and Students
}

\author{
Martin Camiré ${ }^{*}{ }^{*} \&$ Pierre Trudel ${ }^{1}$ \\ ${ }^{1}$ School of Human Kinetics, University of Ottawa, Ottawa, Canada \\ *Corresponding author: School of Human Kinetics, University of Ottawa, Ottawa, ON, K1N 6N5, Canada \\ Tel: 1-613-562-5800 (6379). E-mail: mcamire@uottawa.ca
}

Received: May 10, 2013

Accepted: May 27, $2013 \quad$ Online Published: June 5, 2013

doi:10.5430/wje.v3n3p40

URL: http://dx.doi.org/10.5430/wje.v3n3p40

\begin{abstract}
In Canada, adolescent boys have been shown to have a higher high school dropout rate compared to girls. This situation is particularly evident in the country's second largest province by population, Quebec. The sport of Canadian football has recently gained in popularity in Quebec as many people believe that the sport can be used to promote both life skills and student engagement. The present study's purpose was to document coaches' and students' perspectives on student development through participation in high school football. Nine coaches and 18 students were interviewed through individual and focus group interviews and shared how they believe that students benefited personally and academically from playing high school football. Nevertheless, both coaches and students faced several challenges during the season that influenced the benefits students gained from their participation in sport. Findings suggest that high school sport, and more specifically high school football, can facilitate the positive development of students. However, to effectively promote student engagement, coaches must continually put in place strategies that help maintain students' motivation toward school.
\end{abstract}

Keywords: development; adolescent; youth; dropout; leadership

\section{Introduction}

Elevated high school dropout rates have been associated with many negative consequences for public health. On an individual level, dropping out is linked with poorer mental health, riskier health behaviours and attitudes, a life-course of underemployment, and lower lifetime earnings (Archambault, Janosz, Morizot, \& Pagani, 2009). At a social level, dropout leads to a less qualified workforce and slower economic growth (Archambault, Janosz, Fallu, \& Pagani, 2009). For example, in Canada, the employment rate of individuals without a high school diploma stands under $40 \%$, putting much pressure on social assistance programs (Richards \& Scott, 2009).

In Canada and particularly in the province of Quebec, adolescent boys are at a higher risk of dropping out of high school than girls. Statistics indicate that $19 \%$ of Quebec males aged 20-24 lack a high school diploma compared to $8.5 \%$ for girls (Richards, 2011). Sport has been identified as an activity that can positively influence students' global development (i.e., physical, social, affective, cognitive) and increase school engagement for those at risk of dropping out (Bailey et al., 2009; Mahoney \& Cairns, 1997). Gould and Carson (2008) argued for the use of sport to foster student development because it attracts an abundance of intrinsically motivated participants. Moreover, a survey by the Canadian organisation True Sport (2011) indicated that sport is a highly valued social practice, ranked by Canadians as the second most positive influence in the lives of adolescents after family.

\section{Literature Review}

High school sport is a developmental activity that attracts many participants. In Canada, over 750000 students practice sport in this setting and according to School Sport Canada (2012), the mandate is to: "promote and advocate for positive sportsmanship, citizenship and the total development of student athletes through interscholastic sport". Researchers have investigated how participation in high school sport can promote life skills and student engagement. Life skills (e.g., leadership, teamwork, time-management) are defined as behavioural, cognitive, interpersonal, and 
intrapersonal skills that enable individuals to succeed in life. Life skills are useful in sport but can also be transferred to help individuals thrive at school, home, and work (Danish, Forneris, Hodge, \& Heke, 2004). Student engagement is defined as students' motivation to remain engaged academically and successfully meet performance expectations (Archambault et al., 2009). Student engagement is a multidimensional concept comprised of behavioural (e.g., extracurricular activity participation), affective (e.g., positive feelings toward school, perceptions of belongingness), and cognitive (e.g., investment in learning, self-regulation strategies) dimensions (Fredricks, Blumenfeld, \& Paris, 2004). Researchers have demonstrated how participation in high school sport can lead to positive outcomes such as improved quality of life and contributions to society. For instance, high school sport participation has been associated with better grades, stronger perceptions of school belonging, higher educational aspirations, higher educational attainment, and higher professional aspirations (Fox, Barr-Anderson, Neumark-Sztainer, \& Wall, 2010; Eccles, Barber, Stone, \& Hunt, 2003; Marsh \& Kleitman, 2003). Furthermore, students participating in high school sport have been shown to have lower levels of depression and emotional distress as well as higher levels of self-esteem and a healthier self-image than non-athletes (Fredricks \& Eccles, 2006; Harrison \& Narayan, 2003). A study conducted by Wilkes and Côté (2010) demonstrated how female basketball players were provided with opportunities to develop emotional regulation, initiative, and prosocial norms through their involvement in high school sport.

Researchers have also examined the perceptions of coaches as it relates to development in high school sport. Coaches in several studies have emphasised the importance of prioritising the physical, psychological, and social development of students by promoting a diverse range of life skills that help students become productive members of society (Gould, Chung, Smith, \& White, 2006; Vella, Oades, \& Crowe, 2011). In order to promote life skills, high school coaches have been found to use a wide array of strategies. For example, some high school football coaches have been shown to treat the teaching of technical/tactical skills and life skills as inclusive pursuits of coaching and have deliberate strategies for life skill development such as holding students accountable, involving students in goal-setting, and discussing life skill transfer (Gould, Collins, Lauer, \& Chung, 2007). Similarly, Camiré, Trudel, \& Forneris (2012) found that coaches use strategies such as conducting peer evaluations, providing students with opportunities to display life skills during practices and games, and involving students in community volunteer activities to make use of life skills beyond the context of sport.

As it relates to students, researchers have examined their perceptions on the benefits as well as the challenges of participating in high school sports. On one hand, students have discussed how they believe that life skills such as time-management, teamwork, and communication can be learned through high school sport participation (Camiré, Trudel, \& Forneris, 2009). Voelker, Gould, and Crawford (2011) conducted a study with students who were captain of their high school team and found that their captaincy experience allowed them to learn important skills such as how to be responsible, accountable, and neutral in conflict situations. One the other hand, researchers have shown how high school sport participation can expose students to discrimination, racism, and a win-at-all-cost attitude that distorts fair play (Buford-May, 2001). Furthermore, high school students have shared how challenging experiences can occur during the practice of high school sports such as the formation of cliques on the team, coaches displaying favoritism, and parents putting excessive pressure (Dworkin \& Larson, 2006).

One particular sport that has recently gained in popularity at the high school level, especially in the province of Quebec, is Canadian football. The sport is very similar to American football apart from minor rule differences and a larger playing surface. In Canada, high school football is played during the fall semester and teams play approximately ten games during a season that spans two to three months. In the province of Quebec, a significant amount of new high school football programs have been created during the past decade. The number of students practicing football in the province has increased from 5742 in 2001 to 13869 in 2011 (Reseau du sport etudiant du Quebec, 2012). Many of these new programs have been created based on the premise that the sport can promote the global development of participants. In fact, Football Quebec (2012), the sport's provincial governing body, communicates that its mandate is to "promote in a general manner the development of physical activity and education to ensure physical, intellectual, and moral development" (translation from French). Some researchers have endeavoured to examine the type of development that can occur for students taking part in high school football but this research has primarily taken place in the United States. For instance, Petitpas, Van Raalte, Cornelius, and Presbey (2004) evaluated Play It Smart, an American high school football program designed to enhance at-risk students' academic, athletic, and personal development. Results indicated that program participants had significantly higher grades than non-participants and $98 \%$ of seniors in the program graduated from high school. Researchers in the United States have also studied the work of high school football coaches. Collins, Gould, Lauer, and Chung (2009) examined the philosophies of ten award-winning football coaches and found that they placed primary 
importance on the psychological, social, and academic development of students. Furthermore, coaches believed that football could be used purposefully to teach students life skills that can be applied on and off the field. Gould et al. (2007) examined the strategies used by these same coaches and found that positive student development was promoted when coaches provided individualised feedback, clearly communicated their expectations, and reinforced the link between football and life.

Based on the findings of the research that has been reviewed, it appears that high school sport and more specifically high school football can be used to promote life skills and student engagement. Nevertheless, it is important to recognise that the positive outcomes of participation in any sport do not occur automatically. In fact, the benefits that can be derived from sport are highly influenced by coaches, whose experiences, training, philosophies, and strategies play significant roles in structuring the sporting environment (Gould \& Carson, 2008). Additionally, students and their internal (e.g., existing life skills, personality characteristics) and external (e.g., parents, peers, socioeconomic status) assets strongly influence the development of life skills and student engagement. Although football has greatly increased in popularity in Canada, to our knowledge, no research has been conducted in a Canadian context to examine the developmental outcomes of participation in this sport from the perspectives of those directly involved, that being coaches and students. Examining more closely the sport of football in contexts other than the United States is warranted, considering the recent proliferation of football programs in Canada and the sport's potential influence on life skill development and student engagement.

The present study's purpose was to document coaches' and students' perspectives on student development through participation in high school football. Four research questions guided the study: (a) What were coaches' developmental expectations for the season and students' motivations to play football?, (b) What strategies were used by coaches to promote life skills and student engagement?, (c) What did coaches and students believe was learned and transferred from playing football, and (d) What challenges did coaches and students face during the season? A qualitative methodology (Grbich, 2007) was used to explore the research questions because it allows for the interpretation of the complex reality of a given situation, in this case, student development through football. Qualitative research offers information about the 'human' side of an issue by providing the varied opinions, emotions, and beliefs of individuals. Richness of description was achieved by reconstructing the meaning of participants' lived experiences and giving their voices substantial textual display.

The conceptual framework guiding the elaboration of this study was informed by the fundamental principles of positive youth development, a strength-based approach to development (Lerner, 2002). According to this approach, human development and social behaviour cannot be reduced to genetic influences as the relative plasticity of human development legitimises an optimistic view for systematic change and adaptive developmental regulations that enable individuals to succeed in life (Lerner, Almerigi, Theokas, \& Lerner, 2005; Roth \& Brooks-Gunn, 2003). Research has demonstrated the possibility of optimising the relationship between individuals and their ecologies by focusing on the learning of positive health behaviours and psychological attributes through sustained adult-youth relationships, skill-building activities, and access to leadership roles (Eccles \& Gootman, 2002). In accordance with positive youth development principles, this study was framed using a strength-based approach to examine the promotion of life skills and student engagement rather than a deficit-reduction approach focused on alleviating undesirable behaviours and eliminating school dropout.

\section{Method}

\subsection{Context}

The current study was part of a larger project on student development through high school football. The research took place at a private high school in the province of Quebec in Canada with an enrolment of approximately 1000 students. The school offers students the opportunity to practice basketball, volleyball, badminton, and soccer. For several years, formal discussions involving various school members (i.e., teachers, administrators, parents) were held to determine how the sports program could further serve the student population by engaging students, especially boys, who did not practice sports and who were at risk of dropping out. During discussions, football was often mentioned for its positive as well as less positive attributes. On one hand, proponents stated that high school football provides opportunities to reach out to a large number of students (teams are often comprised of over 50 individuals) and the sport has often been associated with the development of important life skills such as dedication, discipline, and hard work (Collins et al. 2009). On the other hand, detractors discussed how the sport is often linked with injuries and is reputed for promoting a chauvinist subculture of violence and aggression. Despite some of the drawbacks, administrators decided to provide the initial financial investment needed to start a football team at the school. During the program's inaugural 
season in 2011, the researchers conducted a project to help coaches promote student development (Camiré \& Trudel, submitted). The present study was conducted concurrently and specifically examined coaches' and students' perspective on development through participation in high school football.

\subsection{Participants}

Coaches $(n=9)$ were all male, were between 23 and 52 years of age $(M=35)$, and had between zero to seven years of experience coaching football $(M=2.5)$. Five coaches were from the external community and four coaches were teachers at the school. All coaches had post-secondary education, including three who held post-graduate degrees. Four of the nine coaches held certifications from Canada's National Coaching Certification Program (NCCP). Out of the team's 46 students, 18 volunteered to take part in the current study. Student participants were all male and were between 14 and 16 years of age $(M=15)$. Eighteen was deemed an appropriate number of students to gain insight on development in the context of high school football. Efforts were made to recruit students on offense, defence, and special teams. Starters, reserves, and captains were also recruited to have participants with varied experiences.

\subsection{Procedure}

Prior to collecting data, the researchers gained approval from the University's Office of Research Ethics and Integrity to conduct the study. Upon approval, a meeting was organised with the school's administrators to explain the study's purpose and to receive their authorisation to interview coaches and students. The football team's nine coaches each participated in two individual semi-structured interviews (one pre-season and one post-season). The 18 students participated, at season's end, in three focus group interviews comprised of six students in each group. Focus groups were used with students because adolescents' comfort level communicating with adults varies considerably and adolescents have been shown to be more relaxed and willing to share perceptions when discussions are held with peers (Horner, 2000). Prior to each individual and focus group interview, coaches and students were reminded of the voluntary nature of the study, explained their rights to confidentiality and anonymity, and signed a consent form. All interviews occurred in person, were audio recorded, and were conducted by the first author. Probing questions were often used to have participants elaborate on certain responses using actual events. Pre-season interviews with coaches ranged from 35 to 63 minutes $(M=48)$ and from 29 to 54 minutes $(M=40)$ for post-season interviews. Focus group interviews with students ranged from 38 to 49 minutes $(M=44)$.

\subsection{Interview Guides}

The interview guide used during pre-season interviews with coaches was composed of two sections: demographic information and expectations. First, coaches were asked to provide their age, occupation, education, coach training, and experiences as athletes and coaches. The aim was to build rapport and better understand coaches' biographies. Second, coaches detailed their approach to coaching and what their expectations were for the upcoming season. Questions included: According to you, what is the mandate of the football program? and What do you intend to coach your students this season? The interview guide used during post-season interviews with coaches was composed of two sections: impressions of the season and developmental outcomes. Examples of questions included: Did you face obstacles this season?, Do you believe students developed by being on the football team?, and Do you believe students can transfer life skills beyond football? The interview guide used during focus group interviews with students was composed of two sections: impressions of the season and interactions with coaches. Questions asked to students included: Why did you want to play football?, Did being on the football team influence your development as a person?, Do you believe coaches facilitated your development as a person?, and Do you believe coaches taught you skills that you can use beyond football?

\subsection{Data Analysis}

Interviews were transcribed verbatim resulting in 268 single-spaced pages of data from coaches and 61 single-spaced pages of data from students. Upon being transcribed, transcripts were sent to coaches via email for them to confirm the accuracy of the responses shared with the researchers and no changes were asked to be made. The software NVivo 9 (NVivo, 2011) was used to organise the interview transcripts which were read by the first author on two occasions to identify preliminary themes. A thematic analysis was performed whereby the data were broken into smaller meaning units and organised in themes and categories (Braun \& Clarke, 2006). A thematic analysis is a flexible method for analysing and reporting qualitative data because it allows for the triangulation of experiences and perceptions of multiple types of participants. The analysis was guided by the recommendations of Fereday and Muir-Cochrane (2006) who developed a hybrid approach of deductive and inductive coding to capture the qualitative richness of phenomena described by participants. Some categories were deductive in nature and were based on the research questions and the strength-based framework of the study (e.g., academic engagement, strategies for positive development, transfer of life 
skills). Other categories were inductive because they emerged directly from the data and were recognised as important patterns representing the beliefs of participants (e.g., challenge of maintaining philosophy, differences between types of coaches). The analytical process was reflective in nature as categories were continuously reviewed by the two authors to ensure that the themes and categories were grounded in the original data and suitably portrayed the subjective viewpoint of participants.

\section{Results}

Results are organised in five sections. First, coaches' developmental expectations for the season and students' motivations to play football are explored. Second, coaches' strategies to promote student development are examined. Third, participants' views on developmental outcomes are provided. Fourth, the skills participants believe can be transferred beyond football are examined. Fifth, the challenges faced by participants are presented. Acronyms are used to protect participants' identity (e.g. Coach $6=$ C6; Student from Focus Group $1=$ SFG1).

\subsection{Expectations and Motivations}

It appears that the football team's mandate was effectively communicated by administrators to coaches. All of the coaches discussed in different ways how their expectations were related to positive development and student engagement: "Football, the first mandate, it's to keep boys motivated at school. That's why we got \$40 $000 \mathrm{CAD}$ because data clearly show boys are not as motivated. Also, many boys weren't on any sport teams and wanted to play football" (C3) and "This program was put in place for boys who are less motivated. It's about developing students. It's the philosophy of the school and all coaches. Academically and personally, to get them to progress" (C6). A coach explained how the school's mandate of attracting boys not involved in other sports was being achieved: "Out of the 80 boys who showed up at training camp, over 50 didn't play sports at the school. It's significant because sport can become important in their lives, keep them in shape, and give them more self-esteem" (C2). Coaches also shared their expectations for the season as it relates to life skill development and student engagement, making reference to specific life skills and how these can transfer to other domains. For example: "What I'd like to work on with my students is leadership and communication. I'd like students to say 'In football, this is what I learned as a person. I'll exhibit this at work, with my friends, with my family" (C9) and "In terms of growth, if students gain in confidence, I'll be happy. Making that link between football and their studies. If a student is confident in football, he can transfer that to the classroom" (C7). Coaches also had clear goals related to student engagement. A coach said: "I'd like my students to complete the academic year, that they don't drop out. That they continue their football careers in college because they loved their experience. So finding ways to encourage students to continue and finish their studies" (C1).

As for students, they had several reasons motivating them to play football. For some, it was because they love the sport: "It's my favourite sport since elementary school. It's the only sport in which I have any talent. When I knew we would have a team, I was motivated to participate" (SFG1). Others were attracted to football's physical nature: "I really like that it's a guy sport, a contact sport. It's the only sport where you can hit someone hard legally. I really liked that. Because there was a team at school, I decided to go" (SFG2). Most students provided reasons for joining the team that are directly linked to the program's mandate. For instance: "Me, I love playing football. When I'm playing football, I'm happy so for sure having a school team motivated me" (PFG1), "There weren't any sports that attracted me at school but when I found out there would be a football team, I told myself I was going to join" (SFG3), and "My entire high school, I wasn't on a sports team at school. This being my last year, football was something I wanted to try" (SFG1). A few students discussed how they had lobbied for years to get a football team and were highly motivated once it finally happened. One student said: "For years we've been asking for a team. We were one of the only schools in the region without a football team. What I really liked was working for it and finally have it happen my last year" (SFG1).

\subsection{Strategies}

Several strategies were employed by coaches throughout the season to promote life skills and student engagement. For example, some coaches mentioned how they taught leadership principles to their students. A coach stated: "I told students to lead by example. A leader is someone who puts himself at the same level as others, you'll be better appreciated. They'll see you as an equal that brings people together" (C8). Students expressed how they learned from coaches the importance of leading by encouraging others. A student said: "Coach would come see us during games and say 'Boys, pump up your teammates'. Really, he wasn't just saying that for football. If you're not motivated to do something, you won't persevere. That transfers well to everyday life" (SFG1). Coaches also had strategies to help students persevere through adversity: 
I try to put students in uncomfortable situations to see how they react because they can discover new things about themselves. Sometimes, I ask students to change positions and they'll say 'coach, I'm not sure if I can do that'. By staying with it, they discover their potential and learn something new so I try to challenge them as much as possible. (C1)

One student discussed how a particular strategy used by coaches helped him persevere:

Coaches told us stories like "I played with a broken ankle". I see it as an example of perseverance. It's by working hard that you reach your goals. It helped us develop as much in football as in life. Those stories, they motivated us, gave us confidence, it's like they were saying "You can do it too, you just have to want it". (SFG1)

As it relates to academics, coaches explained how they would take time to specifically discuss important issues with students: 'I'd talk to seniors and say 'Does college football interest you?'. They'd answer 'Yeah, I want to try out'. I'd talk about how good grades are needed for college and during the season, I saw how they prioritised school" (C8) and "I'd tell them 'Look, focus at school. I see how you're focused here, you work as a team, you put in the effort, why don't you put in the same effort at school?"' (C4). One coach expressed how he worked to find ways to help students persevere academically: "I told students that if they had problems in a certain subject to come and see me. I'd try to help them or go see the head coach to find tutors to guide them in the right direction" (C8). Some students discussed how coaches would approach them to address academic matters. One student stated: "It wasn't me who would approach them. They'd come see me. Coach heard that I didn't have good grades and fooled around in class. He pushed me to improve, to stay on the team" (SFG3). Some coaches explained how because football is only practiced during the first three months of the school year, they have various initiatives planned to keep students engaged and motivated in the offseason. Two coaches stated: 'Students always ask me 'Hey coach, when do we start training again?' In January, we'll train in the morning, plyometrics, running. We're organising all of that and we hope they jump right in" (C7) and:

I email my students to ensure the season is not over even when last game has been played. Students need responsibilities to make them conscious that they're still on the football team. We lack presence in the offseason so my objective is to follow my guys and ask them "Did you run today?" for them to feel that we're monitoring them. (C5)

\subsection{Developmental Outcomes}

At season's end, coaches and students discussed how being part of the football team enabled a number of students to develop life skills and remain engaged academically. Coaches shared how they believe some students were able to develop and exhibit leadership. Two coaches stated: "Our running back, we named him captain toward year's end because of how he behaved on the field. He's a shy guy but when he said something, people listened. If someone benefited, it was him, we encouraged him enormously" (C2) and "I saw many, I'd say a dozen that came out as leaders. Not just captains but others that became leaders because they put in the effort, didn't complain. We had good surprises" (C4). Students also discussed how they believe they developed leadership skills. One student said: "I developed because I was never a captain before this year, I didn't know what it was. When I heard people saying 'We're going to lose', on the sideline, I needed to be an example, to keep people motivated" (SFG1). Coaches believed that students also learned about perseverance. A coach said: "I saw improvements. They understand what it takes to be a great team. It's on the field, it's during practice. It implies never quitting. It's going to help them in many other things later in life" (C5). Similarly, two students mentioned: "I learned to put my all every minute, every play. At first, I didn't get it and I got discouraged. After that, I told myself, every play counts" (SFG2) and "Those are things you learn. You can never quit. There is light at the end of the tunnel. It was a really good experience to learn this mind set of always trying to do your best" (SFG2).

In addition to developing important life skills, coaches commented on how they believe some students' participation in high school football increased their school engagement. For example, one coach said: "From my own eyes, I'd tell you four or five students that I observed. Students I taught last year. I was really amazed by what they accomplished in football this year and I know things steadied at school also" (C4). The students discussed how playing football motivated them to be engaged academically. Three students stated: "Me, it was my motivation because sometimes in the morning I'd say "Ah no, school! Ah well at least I have football after"" (SFG1), "Because of football, I really work hard at school. I try to be better because I want to be on the team next year" (SFG3), and "If it wasn't for football, I wouldn't be here right now. I'm here because of football. I don't have super good grades but I work hard because I want to stay here" (SFG3). Some students mentioned how being a member of the football team gave them a stronger connection to the school. One student said: "It's the sense of belonging. I bought a team coat on which it's written [name of school] at the back. I'm proud to wear it and represent our school. That I really developed" (SFG2). For others, football allowed them to cultivate social bonds with peers and feel like they belong to a team: "It's that team spirit. It allowed me to develop new relationships. Your football friends, you know they'll be there for you. You have a bigger 
circle of friends and it helps you" (SFG3) and "When you have nearly 50 guys that make up a team, guys that are together, it creates a huge sense of belonging" (SFG1).

\subsection{Transfer}

Both coaches and students believed that the life skills learned in football can be transferred and applied outside of sport. One coach explained how perseverance is an important attribute to develop in football that can also be applied at work: "To persevere, no matter what you do, you need to put in the effort. I think they see that you always have to push yourself. It will help them in the context of work" (C8). A coach provided a concrete example of how he intentionally teaches perseverance as a transferable skill: "Take perseverance, I say 'Should I get discouraged after two straight losses? No. Should I get discouraged after two straight unsuccessful job interviews? No.' I try to make those parallels that football is the same as life" (C9). While discussing transfer, a coach illustrated the case of one particular student: "Take the example of [student], an offensive lineman. He's one of the smallest guys on the team but he really gained in confidence and leadership. I think he applies this in everyday life and at school" (C6). Although most coaches acknowledged talking to their students about transfer, one coach stated it is not necessary to do so because he believes transfer occurs automatically:

I have the impression that it happens more by osmosis. Students grasp those things without us having to tell them. They won't realise it but it will become routine. That's the beauty of sport, you accomplish things without realising the benefits. It happens naturally. (C2)

As for students, based on their responses, it appears that many understood that the skills learned in sport can be applied in a variety of settings. One student explained how he believes that what he learned in football will be useful at work: "I was happy to have developed teamwork and leadership because I'm counting on going into management. You really need to be a leader and it helps when you've had experiences. I think my experiences in football will transfer"' (SFG1). Another student said that balancing school and football helped him develop time-management skills: "Football is strict. That helped me outside of football. I work harder to have good grades. I plan my week to organise football, homework and other things. It teaches me to balance things" (SFG3). One particular student was able to put his involvement in football in perspective: "I find having good grades is as important as performing in football because we won't be playing football our entire lives. If we can apply what we've learned in football in real life, it's better" (SFG3).

\subsection{Challenges}

Although it appears that positive development and transfer occurred for a large number of students, coaches and students mentioned facing several challenges during the school year. First, coaches often found it challenging to promote the development of all students: "Students don't all react the same. Some progressed but for others, there was no progress. In a team, some student won't progress" (C4). Two coaches elaborated on this notion and explained how the perceived lack of development was mostly observed in senior students: "Seniors, I'll be honest, I don't think they developed as much as I would've wanted them to. I heard teachers complain about football students with inflated egos who think they're above everyone, it's disappointing" (C3) and "I thought that it would've motivated them to be calm and focused at school but for some no. We received negative comments from teachers, the administration. I teach seniors and would've liked to see more progression" (C7).

Second, coaches and students mentioned how there was a noticeable decrease in student engagement at season's end. A coach said: "In terms of effort, I'd tell you there was a let-down. After football, guys were discouraged that the season was over" (C6). For their part, students discussed how not having football as part of their routine created a big void which ultimately affected their engagement at school. Two students stated: "My grades have gone down slightly since football has stopped" (SFG3) and "Since football is over, it feels like I have nothing to do. I'm home and I'm bored. I decided to start training again by myself. I think it was the motivation I needed" (SFG1).

Third, due to high school football's competitive nature, coaches stated how it was often difficult to keep in mind the program's focus of promoting development and student engagement. One coach explained how he literally lost control of his emotions during a tightly contested game: "I wasn't calm. I was really involved on the side-line. It's something I'm not happy about. I didn't really lose it on a student but I did on referees at one point" (C5). Another coach explained how, during a practice, he did not take seriously an activity that was specifically planned to promote the development of students: "That activity took away practice time. We wanted to get ready for the upcoming game. We didn't take it seriously, it's our error. We should've worked more on that. When you do something, you should do it right" (C6).

Finally, when asked to assess student development, coaches who were not teachers at the school and came from the community found it challenging to determine whether or not students developed life skills: "It's hard for me to see if 
they developed skills. I don't know if they really have them because I only see them three times a week. I think teacher-coaches can better determine that" (C9). Teacher-coaches provided examples of how they believe they are in a preferred position to assess development when compared to their counterparts from the community: "There are many students to whom I teach. I can follow them in two ways. I got involved with the football team to be closer to students" (C6) and:

There is a student on the team, when he started high school, his grades fell drastically and he nearly dropped out. He didn't have any friends. With football, I saw it because I teach him, he gained in confidence. He saw himself as a leader. His attitude changed, he socialised and made friends. I know that for him, the football team, it saved him. (C3)

A teacher-coach explained how his dual role allows him to interact frequently with parents and discuss issues related to student development: "Lots of parents came to see me during and after the season. They'd tell me 'His attitude at home, at school changed.' I had lots of comments like that" (C7).

\section{Discussion}

\subsection{Development and Transfer}

It appears that the purpose of the football team was effectively communicated to coaches who all had objectives for the season that were related to promoting life skills and student engagement. Moreover, based on participants' responses, it appears that many of these objectives were attained. For example, coaches indicated that the football team mainly attracted boys who did not previously take part in the school's sports program. Students discussed how they believe playing football helped them feel connected to their school, cultivated a sense of belonging to a team, expanded their social network, and allowed them to develop organisational skills. These findings support previous research demonstrating the potential benefits of school sport participation (Bailey et al., 2009; Eccles et al., 2003) and illustrate how being part of a high school football team can foster the behavioural, affective, and cognitive dimensions of student engagement (Archambault et al., 2009; Fredricks et al., 2004). Although findings are encouraging, to comprehensively understand the influences of high school sports such as football on student engagement, additional research is needed to identify the psychological and social mechanisms that lead to increased student motivation and academic engagement.

In terms of the strategies employed to promote life skills and student engagement, participants discussed how coaches taught leadership principles, put students in uncomfortable positions, shared personal stories of perseverance, talked about college, and offered students training activities in the offseason. These findings are consistent with previous research (Collins et al., 2009; Gould et al., 2007) and suggest that the coaches in the current study understood the importance of using sport as a tool to teach students life skills. Based on positive youth development principles, coaches adopted a strength-based approach and made conscious efforts to expose students to situations where they add opportunities to develop in a positive manner (Lerner et al., 2005; Roth \& Brooks-Gunn, 2003). Findings suggest that the strategies used by coaches led to positive developmental outcomes as both coaches and students believed that vital life skills were learned and transferred to school, work, and other settings. Camiré et al. (2012) demonstrated how high school coaches who deliberately integrate life skill strategies in their coaching practice can promote the development of students and help them better understand the concept of transfer. Using Gould and Carson's (2008) theoretical levels of life skills development, it appears that coaches in the current study were able to work at levels three (designing activities to teach life skills) and four (teaching for transfer). Nevertheless, it is essential to acknowledge that one of the team's coaches assumed that transfer is an outcome that occurs automatically. This notion has also been observed in previous studies conducted with high school coaches (e.g., Lacroix, Camiré, \& Trudel, 2008). According to Gould and Carson's (2008) model of coaching life skills through sport, transfer is not an automatic process and many factors such as (a) comprehension of the concept of transfer, (b) awareness of skills learned in sport, (c) knowledge of transfer situations, and (d) social support greatly influence athletes' ability to transfer skills. Therefore, when it comes to promoting the transfer of life skills, it is recommended that coaches adopt a deliberate approach and give their students the knowledge and confidence necessary to apply their skills in various settings.

\subsection{Challenges}

A key contribution of the current study lies in demonstrating some of the challenges faced by coaches in promoting life skills and student engagement. First, coaches expressed a certain level of disappointment as football did not have a positive influence on one particular group of students. It is essential to understand that sport is not a panacea and as Danish and Nellen (1997) stated: "while sport provides a model for enhancing competence, sport by itself does not enhance competence" (p. 102). In fact, Hansen and Larson (2007) demonstrated how time invested, motivations to 
participate, and access to leadership roles are all factors related to the developmental gains experienced by youth in organised activities. Additionally, Guest and Schneider (2003) discussed how the social context of schools influences the developmental outcomes associated with participation. Therefore, it is plausible that some students did not appear to benefit from their involvement on the football team because they did not dedicate themselves, had alternate motives for participation, or simply were not granted appropriate opportunities to develop life skills such as leadership. Football presents particular challenges when it comes to facilitating development because teams are significantly larger than other popular high school sports such as basketball and volleyball, making it difficult for coaches to exert a positive influence on each and every student.

A second challenge consisted of finding ways to maintain student engagement at season's end once students were no longer directly involved in football-related activities. Coaches explained how they had initiatives in the offseason designed to interact with students and maintain their motivation; however the actual effectiveness of these strategies remains unknown. Additional research is needed to identify strategies coaches can use to effectively occupy students' time and uphold their engagement during the entire school year. As Petitpas, Cornelius, Van Raalte, and Jones (2005) discussed, positive developmental outcomes occur when adult leaders interact with youth in a consistent and prolonged manner and form quality relationships. Therefore, it is recommended that coaches work to develop meaningful activities that allow them to interact with students during the nine months of the year when football is not practiced.

A third challenge faced by coaches consisted of getting caught up in the competitive aspect of football and placing too much emphasis on performance to the detriment of student development. Researchers have discussed the 'sport as business' mentality prevailing in many high school sports, such as football and basketball, as athletes compete for university athletic scholarships (Danish et al., 2004). However, of the millions of children who play sports, very few will compete at the university and/or professional levels. For that very reason, coaches should always find ways to remind themselves of the developmental mandate of high school sport (Danish \& Nellen, 1997; Gould \& Carson, 2008). One way of doing so consists of having coaches take time to reflect and write down on paper their coaching philosophy, preferably focused on the psychosocial development of students (Camiré, Forneris, Trudel, \& Bernard, 2011). Moreover, it is recommended that coaches share their philosophy with others and consult it on a regular basis to ensure a close link between their principles and actual behaviours.

Finally, it was discussed how differences existed between teacher-coaches and coaches from the community. Findings suggest that the nature of coaches' involvement at school appears to impact their ability to influence and assess student development. Coaches from the community interacted with students during practices and games whereas teacher-coaches had daily interactions with students and opportunities to closely monitor their academic progress. As discussed earlier, the quality and density of social interactions formed between youth and adult leaders are central factors influencing positive development (Petitpas et al., 2005). As a result, more research is needed to better understand the nature of coaches' involvement at school how it impacts their ability to influence student development.

\section{Conclusion}

Readers should note that this study was conducted within a particular context, consisting of a small sample of male participants who were involved in one particular sport at a single high school. Therefore, the findings are limited in their generalizability. Nevertheless, the use of a qualitative methodology allowed for the study's four research questions to be answered through complex descriptions, from the perspectives of coaches and students, of life skill development and student engagement in Canadian high school football. Findings suggest that football helped students learn life skills, develop a connectedness to school, and remain engaged academically. These findings support past research and contribute to the cumulative empirical evidence demonstrating the positive influences of school sport on students' global development (Bailey et al., 2009). A useful contribution of this research to the study of youth development through sport consists of having explored the challenges associated with promoting life skills and student engagement. Findings clearly indicate how coaches must work to continuously maintain a developmental philosophy and implement strategies to uphold student engagement throughout the entire school year. It appears that teacher-coaches, by the very nature of their role, might be in an advantageous position to positively influence and assess student development when compared to their counterparts from the community. However, before definitive conclusions can be drawn and communicated on this particular matter, additional research must be conducted, especially from a longitudinal perspective by looking at the extent to which transfer occurs over time. Furthermore, comparative studies should be conducted to measure the contribution to development of extracurricular activities other than football, such as music, the arts, and other popular school sports. 


\section{References}

Archambault, I., Janosz, M., Morizot, J., \& Pagani, L. (2009). Adolescent behavioral, affective, and cognitive engagement in school: Relationship to dropout. Journal of School Health, 79, 408-415. http://dx.doi.org/10.1111/j.1746-1561.2009.00428.x

Archambault, I., Janosz, M., Fallu, J. S., \& Pagani, L. (2009). Student engagement and its relationship with early high school dropout. Journal of Adolescence, 32, 651-670. http://dx.doi.org/10.1016/j.adolescence.2008.06.007

Bailey, R., Armour, K., Kirk, D., Jess, M., Pickup, I., Sandford, R., \& BERA. (2009). The educational benefits claimed for physical education and school sport: An academic review. Research Papers in Education, 24, 1-27. http://dx.doi.org/10.1080/02671520701809817

Braun, V., \& Clarke, V. (2006). Using thematic analysis in psychology. Qualitative Research in Psychology, 3, 77-101. http://dx.doi.org/10.1191/1478088706qp063oa

Buford-May, R. A. (2001). The sticky situation of sportsmanship: Contexts and contradictions in sportsmanship among high school boys basketball players. Journal of Sport \& Social Issues, 25, 372-389. http://dx.doi.org/10.1177/0193723501254003

Camiré, M., Forneris, T., Trudel, P., \& Bernard, D. (2011). Strategies for helping coaches facilitate positive youth development through sport. Journal of Sport Psychology in Action, 2, 92-99. http://dx.doi.org/10.1080/21520704.2011.584246

Camiré, M., \& Trudel, P. (submitted). A collaborative partnership to help youth sport coaches integrate psychological skills in their coaching practice. Qualitative Research in Sport, Exercise, and Health.

Camiré, M., Trudel, P., \& Forneris, T. (2009). High school athletes' perspectives on support, negotiation processes, and life skill development. Qualitative Research in Sport and Exercise, 1, 72-88. http://dx.doi.org/10.1080/19398440802673275

Camiré, M., Trudel, P., \& Forneris, T. (2012). Coaching and transferring life skills: Philosophies and strategies used by model high school coaches. The Sport Psychologist, 26, 243-260.

Camiré, M., Werthner, P., \& Trudel, P. (2009). Mission statements in sport and their ethical messages: Are they being communicated to practitioners? Athletic Insight, 11, 75-85.

Collins, K., Gould, D., Lauer, L., \& Chung, Y. (2009). Coaching life skills through football: Philosophical beliefs of outstanding high school football coaches. International Journal of Coaching Science, 3, 29-54.

Danish, S., Forneris, T., Hodge, K., \& Heke, I. (2004). Enhancing youth development through sport. World Leisure, 34, 38-49. http://dx.doi.org/10.1080/04419057.2004.9674365

Danish, S. J., \& Nellen, V. C. (1997). New roles for sport psychologists: Teaching life skills through sport to at-risk youth. Quest, 49, 100-113. http://dx.doi.org/10.1080/00336297.1997.10484226

Dworkin, J., \& Larson, R. (2006). Adolescents' negative experiences in organized youth activities. Journal of Youth Development, 1, 1-19.

Eccles, J. S., Barber, B. L., Stone, M., \& Hunt, J. (2003). Extracurricular activities and adolescent development. Journal of Social Issues, 59, 865-889. http://dx.doi.org/10.1046/j.0022-4537.2003.00095.x

Eccles, J., \& Gootman, J. A. (2002). Community programs to promote youth development. Washington: National Academy Press.

Fereday, J., \& Muir-Cochrane, E. (2006). Demonstrating rigor using thematic analysis: A hybrid approach of inductive and deductive coding and theme development. International Journal of Qualitative Methods, 5, 80-92.

Football Quebec. (2012). Who we are: Mandate of the federation. Retrieved from Football Quebec website: http://www.footballquebec.com/

Fox, C. K., Barr-Anderson, D., Neumark-Sztainer, D., \& Wall, M. (2010). Physical activity and sports team participation: Associations with academic outcomes in middle school and high school students. Journal of School Health, 80, 31-37. http://dx.doi.org/10.1111/j.1746-1561.2009.00454.x

Fredricks, J. A., Blumenfeld, P. C., \& Paris, A. H. (2004). School engagement: potential of the concept, state of the evidence. Review of Educational Research, 74(1), 59-109. http://dx.doi.org/10.3102/00346543074001059

Fredricks, J. A., \& Eccles, J. S. (2006). Is extracurricular participation associated with beneficial outcomes? 
Concurrent and longitudinal relations. Developmental Psychology, 42, 698-713. http://dx.doi.org/10.1037/0012-1649.42.4.698

Gilbert, W. D., \& Trudel, P. (2004). Role of the coach: How model youth team sport coaches frame their roles. The Sport Psychologist, 18, 21-43.

Gould, D., \& Carson, S. (2008). Life skills development through sport: Current status and future directions. International Review of Sport \& Exercise Psychology, 1, 58-78. http://dx.doi.org/10.1080/17509840701834573

Gould, D., Collins, K., Lauer, L., \& Chung, Y. (2007). Coaching life skills through football: A study of award winning high school coaches. Journal of Applied Sport Psychology, 19, 16-37. http://dx.doi.org/10.1080/10413200601113786

Gould, D., Chung, Y., Smith, P., \& White, J. (2006). Future directions in coaching life skills: Understanding high school coaches' views and needs. Athletic Insight, 8, 1-9.

Grbich, C. (2007). Qualitative Data Analysis: An Introduction. London: Sage.

Guest, A., \& Schneider, B. (2003). Adolescents' extracurricular participation in context: The mediating effects of schools, communities, and identity. Sociology of Education, 76, 89-109. http://dx.doi.org/10.2307/3090271

Hansen, D. M., \& Larson, R. W. (2007). Amplifiers of developmental and negative experiences in organized activities: Dosage, motivation, lead roles, and adult-youth ratios. Journal of Applied Developmental Psychology, 28, 360-374. http://dx.doi.org/10.1016/j.appdev.2007.04.006

Harrison, P. A., \& Narayan, G. (2003). Differences in behavior, psychological factors, and environmental factors associated with participation in school sports and other activities in adolescence. Journal of School Health, 73, 113-120. http://dx.doi.org/10.1111/j.1746-1561.2003.tb03585.x

Horner, S. D. (2000). Using focus group methods with middle school children. Research in Nursing \& Health, 23, 510-517. http://dx.doi.org/10.1002/1098-240X(200012)23:6<510::AID-NUR9>3.0.CO;2-L

Lacroix, C., Camiré, M., \& Trudel, P. (2008). High school coaches' characteristics and their perspectives on the purpose of school sport participation. International Journal of Coaching Science, 2, 23-42.

Lerner, R. (2002). Concepts and theories of human development ( $3^{\text {rd }}$ ed.). Mahwah, NJ: Lawrence Erlbaum.

Lerner, R., Almerigi, J. B., Theokas, C., \& Lerner, J. V. (2005). Positive youth development: A view of the issues. Journal of Early Adolescence, 25, 10-16. http://dx.doi.org/10.1177/0272431604273211

Mahoney, J. L., \& Cairns, R. B. (1997). Do extracurricular activities protect against early school dropout? Developmental Psychology, 33, 241-253. http://dx.doi.org/10.1037/0012-1649.33.2.241

Marsh, H. W., \& Kleitman, S. (2003). School athletic participation: Mostly gain with little pain. Journal of Sport \& Exercise Psychology, 25, 205-228.

NVivo (2011) (Version 9.0) [Computer software]. Doncaster, Australia: Qualitative Solution and Research.

Petitpas, A. J., Cornelius, A. E., Van Raalte, J. L., \& Jones, T. (2005). A framework for planning youth sport programs that foster psychosocial development. The Sport Psychologist, 19, 63-80.

Petitpas, A. J., Van Raalte, J. L., Cornelius, A. E., \& Presbey, J. (2004). A life skills development program for high school student-athletes. The Journal of Primary Prevention, 24, 325-334. http://dx.doi.org/10.1023/B:JOPP.0000018053.94080.f3

Richards, J. (2011). School dropout: Who are they and what can be done? Retrieved from C. D. Howe Institute website: http://www.cdhowe.org/pdf/ebrief_109.pdf

Richards, J., \& Scott, M. (2009). Aboriginal education: Strengthening the foundations. Ottawa: Canadian Policy Research Networks.

Reseau du sport etudiant du Quebec. (2012). Annual report. Retrieved from the Reseau du sport etudiant du Quebec website: http://www.sportetudiant.com/fre/ Federation/1105.cfm

Roth, J. L., \& Brooks-Gunn, J. (2003). What exactly is a youth development program? Answers from research and practice. Applied Developmental Science, 7, 94-111. http://dx.doi.org/10.1207/S1532480XADS0702_6

Trudel, P., \& Camiré, M. (2009). Survey on the practice of school sport in Quebec: Phase 2 Report. Ottawa: University of Ottawa. (28 pages). 
True Sport. (2011). Key Facts: Community Sport in Canada. Retrieved from True Sport website: http://www.truesportpur.ca/files/tsreport/TrueSport-TSRKeyFacts-E.pdf

Vella, S., Oades, L., \& Crowe, T. (2011). The role of the coach in facilitating positive youth development: Moving from theory to practice. Journal of Applied Sport Psychology, 23, 33-48. http://dx.doi.org/10.1080/10413200.2010.511423

Voelker, D. K., Gould, D., \& Crawford, M. J. (2011). Understanding the experience of high school sport captains. The Sport Psychologist, 25, 47-66.

Wilkes, S., \& Côté, J. (2010). The developmental experiences of adolescent females in structured basketball programs. PHENex, 2, 1-21. 